\title{
Ponticulus posticus: Anatomical Variation in Posterior Arch of the Atlas Vertebra Evaluated in Lateral Cephalometric Radiography
}

\author{
Sabryna Renata Closs ${ }^{1}$, Alexandre Rodrigues Freire ${ }^{1}$, Sarah Teixeira Costa ${ }^{1}$, \\ Rafael Araujo ${ }^{1}$, Felippe Bevilacqua Prado ${ }^{1}$, Eduardo Daruge Júnior ${ }^{2}$ \\ and Ana Cláudia Rossi ${ }^{1^{*}}$ \\ ${ }^{1}$ Anatomy Division, Department of Morphology, Piracicaba Dental School, University of Campinas - \\ UNICAMP, Piracicaba, SP, Brazil. \\ ${ }^{2}$ Forensic Dentistry Division, Department of Social Odontology, Piracicaba Dental School, \\ University of Campinas - UNICAMP, Piracicaba, SP, Brazil.
}

Authors' contributions

This work was carried out in collaboration between all authors. Authors ACR, EDJ, RA and FBP designed the study, performed the statistical analysis, wrote the protocol and wrote the first draft of the manuscript. Authors SRC, ARF and STC managed the analyses of the study. Authors ARF, STC and ACR managed the literature searches. All authors read and approved the final manuscript.

Article Information

DOI: 10.9734/BJMMR/2017/30378

Editor(s):

(1) Mohammed Rachidi, Molecular Genetics of Human Diseases, French Polynesia, University Paris 7 Denis Diderot, Paris, France.

Reviewers:

(1) Ismail Mikdat Kabakus, Erzurum State Hospital, Turkey. (2) Melinda Danowitz, College of Osteopathic Medicine, New York Institute of Technology, USA (3) Satheesha Nayak, Melaka Manipal Medical College, Manipal University, India. (4) Ali Al Kaissi, Ludwig Boltzmann Institute of Osteology, Vienna, Austria. Complete Peer review History: http://www.sciencedomain.org/review-history/19350

Original Research Article

Received $6^{\text {th }}$ November 2016 Accepted $2^{\text {nd }}$ February 2017

Published $5^{\text {th }}$ June 2017

\section{ABSTRACT}

Aims: To evaluate the prevalence of the Ponticulus posticus in a Brazilian sample and discuss about the importance of this anatomical variation in forensic dentistry area.

Study Design: Observational and transversal study.

Place and Duration of Study: Department of Morphology, Anatomy division, Piracicaba Dental School, University of Campinas-UNICAMP, between June 2014 and December 2015.

Methodology: We used 242 lateral cephalometric radiographs of adult individual skulls from both 
sexes (from 18-60 years old). The sample was divided into the following groups: 92 lateral radiographs of males, and 150 lateral radiographs of females. The visual assessment method was performed by the same examiner. Classification form was carried out in three categories in both sexes: Presence of Ponticulus posticus with complete ossification; presence of Ponticulus posticus with incomplete ossification and absence. Data were performed a descriptive analysis by a decision tree. The sample data were segmented by sex, posteriorly by the presence of Ponticulus posticus, and then as complete or incomplete. Also were applied chi square test to analyze the correlation between the presence or absent of the Ponticulus posticus in relation about sex and the correlation about the Ponticulus posticus is complete or incomplete. The significant level was adjusted to $5 \%$.

Results: From the total sample of 242 individuals, 92 (38.02\%) were male sex and $150(61.98 \%)$ were female sex. Among the male ones, 19 (7.85\%) had shown Ponticulus posticus with 10 $(4.13 \%)$ of them presenting incomplete foramen ossification and the other $9(3.72 \%)$ presenting complete foramen ossification. Concerning the females ones, $34(14.05 \%)$ exhibited this anatomical variation, being $21(8.68 \%)$ incomplete and $13(5.37 \%)$. In general, there was no sex influence (chi-square, $p=0.8354399$ ) in the presence of Ponticulus posticus, indicating that sex is not an influence factor.

Conclusion: The presence of this anatomical variation cannot be related to sexual dimorphism.

Keywords: Anatomy; cervical atlas; sex characteristics; sex dimorphism; Ponticulus posticus.

\section{INTRODUCTION}

Ponticulus posticus is a variation occurring on the Atlas vertebra [1-10]. It is defined as an abnormal small bony bridge [11,12] or an anomalous foramen [13]. This variation is a result of complete or incomplete ossification of the posterior atlanto-occipital membrane along the groove of the vertebral artery, resulting in a foramen, which contains the vertebral artery branch and posterior spinal nerve C1 [14]. If this foramen diameter is reduced it could cause considerable ischemic compression of the vertebral artery with consequent reduction of cerebral blood flow [2].

In the literature, the incidence of the Ponticulus posticus has been reported to be between $5.14 \%$ and $37.83 \%$ in the western population $[11,12,15]$.

The knowledge of the anatomical variations of bony tissue helps us in the analysis of differential characters in individuals who require forensic identification. The forensic analysis is heavily focused on identification of diseased people. Human identification is a major challenge in forensic dentistry practice, for example, especially when the integrity of the body is compromised, such as during mass disasters, wars, explosions, traffic accidents, and assault [16]. The primary aim of forensic anthropology is the reconstruction of an osteobiography, consisting of a set of biological attributes [16].
Previous studies [17-21] confirmed the accuracy of lateral cephalometric radiography. It can be used in the verification of craniofacial anatomical structures to develop discriminant functions.

Atlas vertebra shows greatest variability among the cervical vertebrae [22]. The study of bone anatomical variations tends to be neglected for a forensic dentistry area in human identifications, being described as occasional or even rare. However, the knowledge of the topographical anatomy of the human craniofacial structures and its variations can be crucial to achieving an accurate diagnosis of the individual identity [23]. Knowledge about anatomical variations is also important for anthropology [22,24,25]. Hence, the aim of our study was to evaluate the incidence of the Ponticulus posticus in a Brazilian sample and discuss about the importance of this anatomical variation in forensic dentistry area.

\section{METHODOLOGY}

We evaluated 242 digital lateral cephalometric radiography, belongs to Department of Morphology, Anatomy division, Piracicaba Dental School, University of Campinas-UNICAMP.

The sample distribution was determined by sex of the individuals. Therefore, sample was divided into the following groups:

- Group 1: 92 male lateral radiographs.

- Group 2: 150 female lateral radiographs. 
Sample selection was based on lateral cephalometric radiographs of the skull which allowed visualization of the posterior arch of the Atlas vertebra. We selected individuals between 18 - 60 years of age, to avoid bone modifications due to aging, growth and development. Dental conditions were not considered. We excluded radiographs where visualization of the posterior arch of the Atlas vertebra was impaired, due to the overlap of the mastoid or occipital process. Individuals who presented birth defects, such as cleft lip and cleft palate, and other conditions or syndromes involving the craniofacial region were excluded from the sample.

For analysis of the Ponticulus posticus, one examiner performed visual assessment method in order to minimize errors. Visual method assessment concerns about evaluate the presence of ossification. The examiner searched for whether the structure was radiopaque or not.

According the presence of the Ponticulus posticus, the radiographs were classified in three categories:

a) The presence of Ponticulus posticus with complete ossification (Fig. 1A);

b) The presence of Ponticulus posticus with incomplete ossification (Fig. 1B);

c) None (Fig. 2).

Statistical analyzes were performed in the software $R$ Core Team ( $R$ Foundation for Statistical Computing, Vienna, Austria) for
Linux (open source). Data were performed a descriptive analysis by a decision tree (Fig. 3).

The sample data were segmented by sex, posteriorly by the presence of Ponticulus posticus, and then as complete or incomplete. Also were applied chi square test to analyze the correlation between the presence or absence of the Ponticulus posticus in relation to sex and the correlation about the Ponticulus posticus is complete or incomplete. The significant level was adjusted to $<0.05$.

\section{RESULTS}

From the total sample of 242 individuals, 92 (38.02\%) were male sex and 150 (61.98\%) were female sex. Among the male individuals, 19 $(7.85 \%)$ had shown Ponticulus posticus with 10 $(4.13 \%)$ of them presenting incomplete foramen ossification and the other 9 (3.72\%) presenting complete foramen ossification. Concerning the females individuals, 34 (14.05\%) exhibited this anatomical variation, being $21(8.68 \%)$ incomplete and 13 (5.37\%) complete.

In general, the rate of positive cases of Ponticulus posticus, irrespective of sex, was significantly lower (chi-squared, $P<0.0001$ ) than negative cases. There was no sex influence (chisquare, $P=.84$ ) in the presence of Ponticulus posticus, indicating that sex is not an
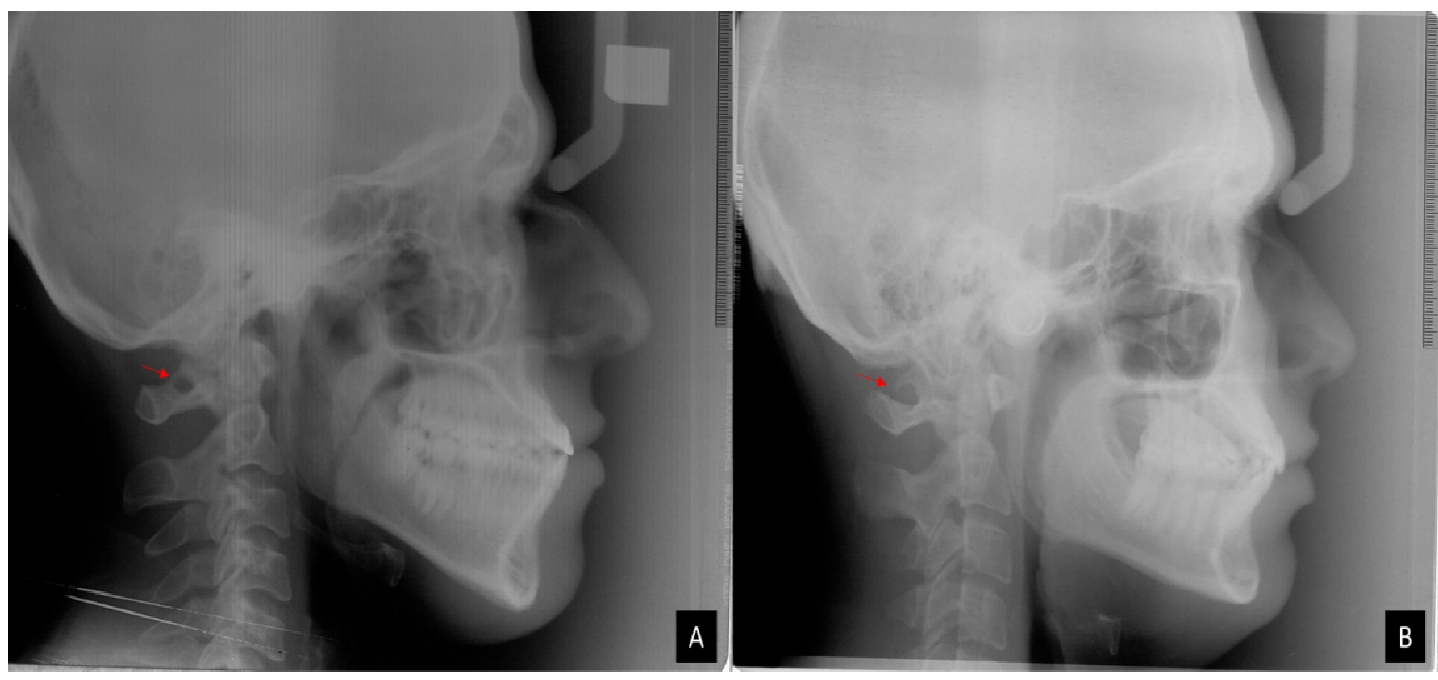

Fig. 1. A) Lateral cephalometric radiography: The arrow indicates Ponticulus posticus B) Lateral cephalometric radiography: The arrow indicates the incomplete ossification of the Ponticulus posticus 


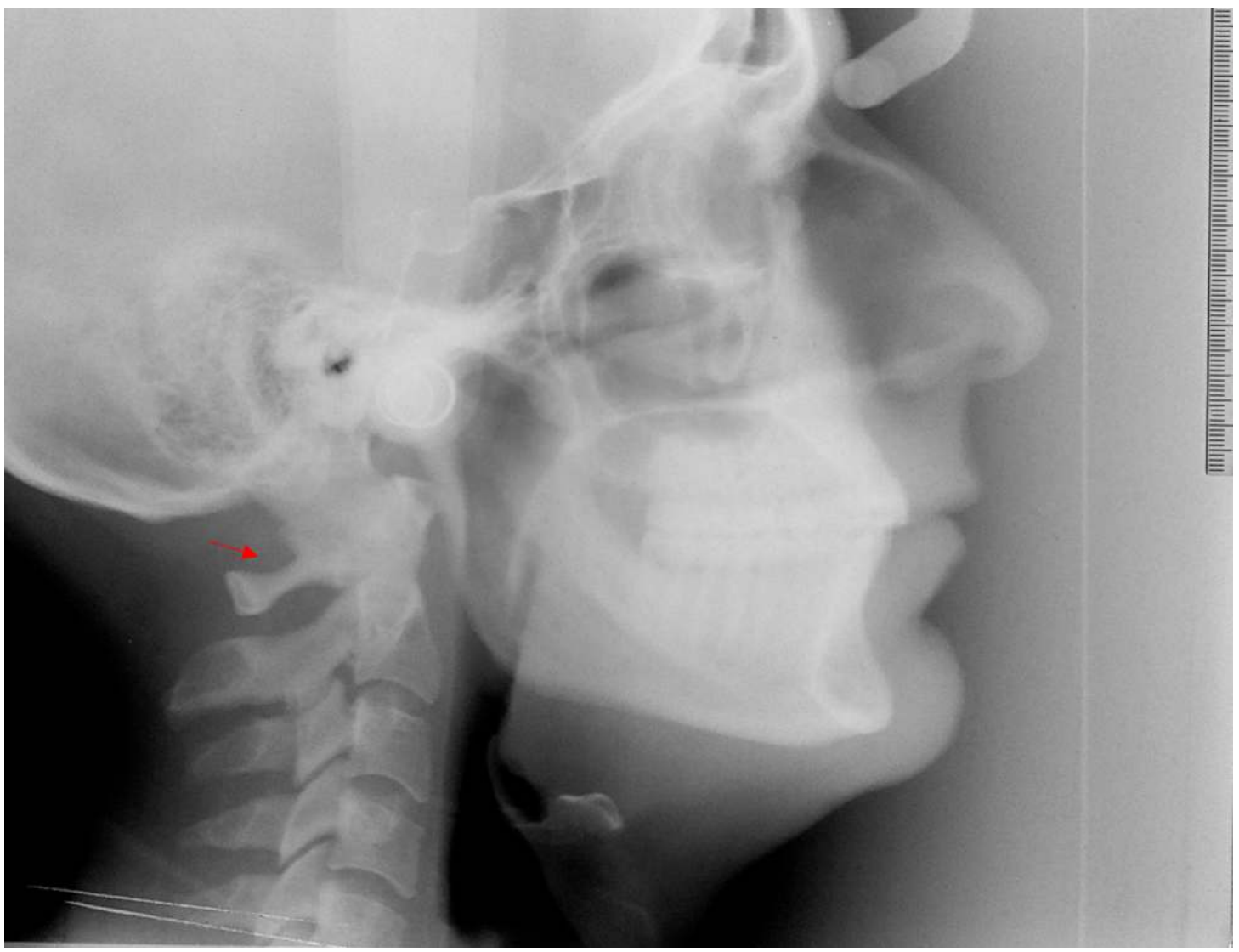

Fig. 2. Lateral cephalometric radiography: The arrow indicates the absence of the Ponticulus posticus

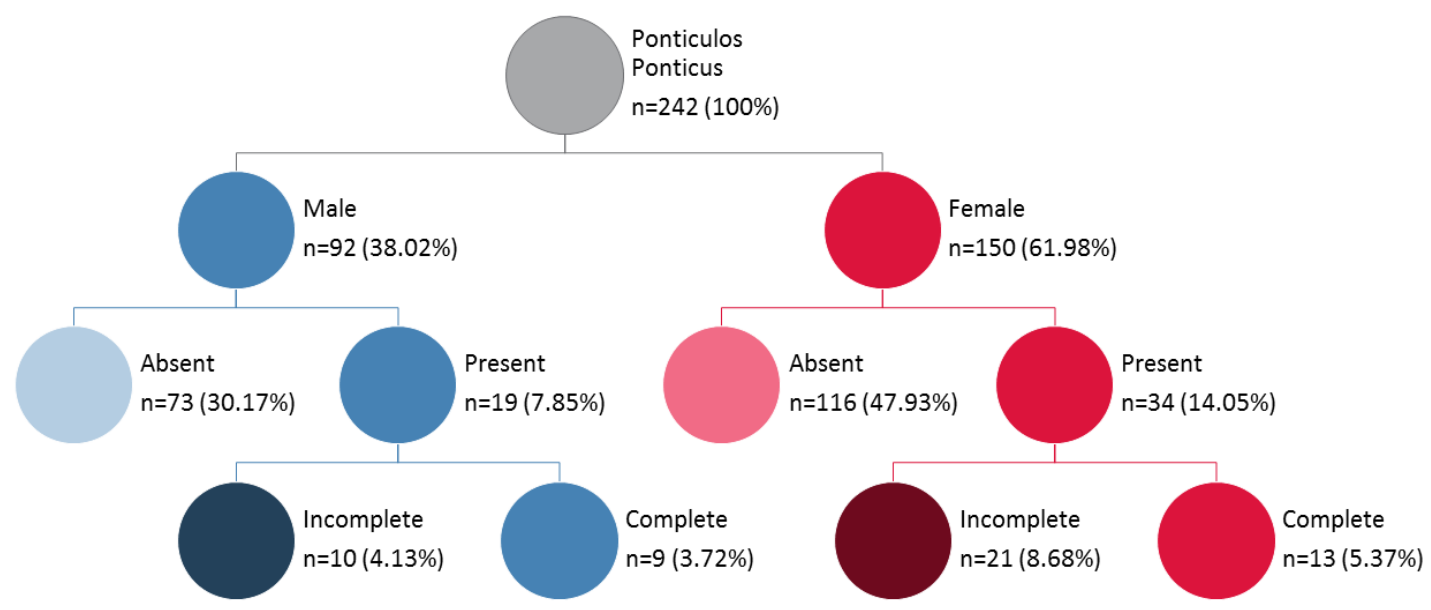

Fig. 3. Decision tree of sample segmented by sex, absence, complete or incomplete presence of Ponticulus ponticus

influence factor. In addition, the incidence of incomplete Ponticulus posticus did not differ (chisquare, $P=.72$ ) from complete ones, based on sex, highlighting the little influence of sex in Ponticulus posticus being incomplete or not (Figs. 4 and 5). 


\section{DISCUSSION}

In dental practice, radiographs are commonly used for diagnostic in maxillo-mandibular structures. Cervical spine can be observed in this type of radiography, but is usually omitted in the cephalometric tracing [6]. Ponticulus posticus is an anatomical variation found in Atlas vertebra, and possible to be detected in lateral cephalometric radiographs $[11,15,26]$.

Ponticulus posticus incidence in the world population is not well established and only little information exists about its morphology in the literature $[9,33]$. In the present study, the Ponticulus posticus was common in $21.89 \%$ of the portion of the assessed Brazilian individuals.
Studies have assessed the incidence of Ponticulus posticus in different populations, as shown in Table 1.

In contrast of studies evaluated in Table 1, the results of our study showed that the higher incidence of the Ponticulus posticus was incomplete in females. Cederberg et al. [30] evaluated Ponticulus posticus presence in 255 radiographs. These authors showed no statistical differences related to sex. In the present study, we evaluated 242 radiographs of Brazilian individuals, which Ponticulus posticus was present in $21.89 \%$. Our study showed no sex influence (chi-square, $P=.84$ ), indicating that sex is not an influence factor.

\section{Sex distribuition of Ponticulus Ponticus in Brazilians}

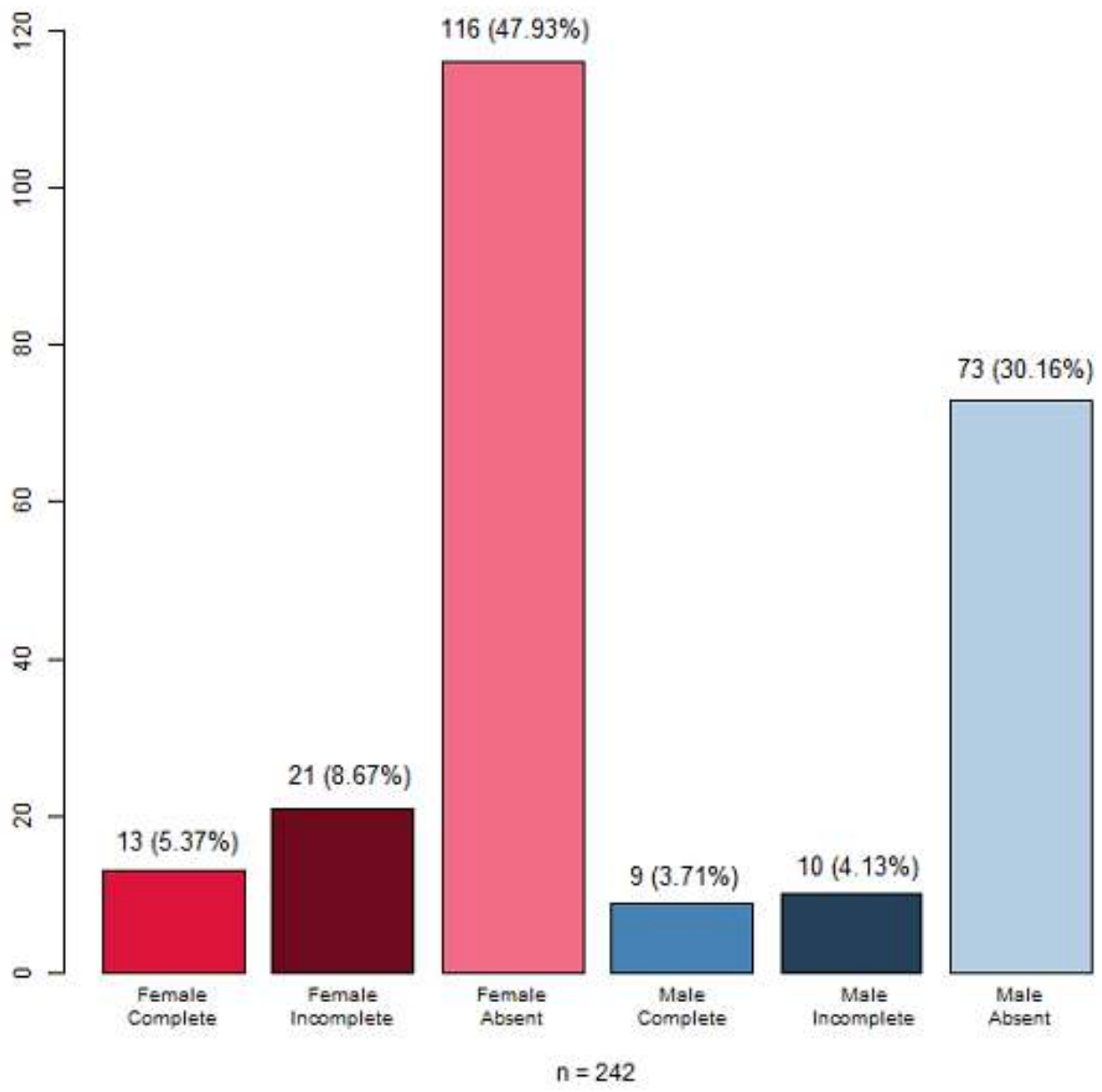

Fig. 4. Sex distribution of Ponticulus ponticus in Brazilians 
Table 1. Ponticulus posticus incidence in the literature

\begin{tabular}{|c|c|c|c|c|c|c|c|}
\hline Reference & Review source & $\begin{array}{l}\text { Total } \\
\text { prevalence }\end{array}$ & Study type & Population & Age & $\begin{array}{l}\text { Female } \\
\text { prevalence }\end{array}$ & $\begin{array}{l}\text { Male } \\
\text { prevalence }\end{array}$ \\
\hline $\begin{array}{l}\text { Wight, et al. } 1999 \\
\text { [9] }\end{array}$ & $\begin{array}{l}895 \text { Lateral cervical } \\
\text { spine x-ray }\end{array}$ & 161 & $\begin{array}{l}\text { Prospective } \\
\text { study }\end{array}$ & Scotland & 42 & 86 & 75 \\
\hline $\begin{array}{l}\text { Bezerra, et al. } \\
2001 \text { [2] }\end{array}$ & Male cadaver & - & Case report & Brazilian & - & - & - \\
\hline $\begin{array}{l}\text { Young, et al. } 2005 \\
\text { [10] }\end{array}$ & $\begin{array}{l}464 \text { neck } \\
\text { radiographics }\end{array}$ & 72 & $\begin{array}{l}\text { Retrospective } \\
\text { study }\end{array}$ & USA & NA & NA & NA \\
\hline \multirow{2}{*}{$\begin{array}{l}\text { Kim et al. } 2007 \\
{[15]}\end{array}$} & $225 \mathrm{CT}$ and & 58 in CT & \multirow{2}{*}{$\begin{array}{l}\text { Retrospective } \\
\text { study }\end{array}$} & \multirow[t]{2}{*}{ Korean } & 45 in CT & 21 in $\mathrm{CT}$ & 37 in CT \\
\hline & $\begin{array}{l}312 \text { lateral } \\
\text { cephalometric }\end{array}$ & $\begin{array}{l}44 \text { in } \\
\text { cephalometric }\end{array}$ & & & $\begin{array}{l}28 \text { in } \\
\text { cephalometric }\end{array}$ & $\begin{array}{l}25 \text { in } \\
\text { cephalometric }\end{array}$ & $\begin{array}{l}19 \text { in } \\
\text { cephalometric }\end{array}$ \\
\hline $\begin{array}{l}\text { Krishnamurthy, et } \\
\text { al. } 2007 \text { [27] }\end{array}$ & $\begin{array}{l}1044 \text { Dry human } \\
\text { atlas }\end{array}$ & 144 & NA & India & NA & NA & NA \\
\hline $\begin{array}{l}\text { Simsek et al. } 2008 \\
\text { [7] }\end{array}$ & $\begin{array}{l}158 \text { dry macerated } \\
\text { atlas }\end{array}$ & 15 & NA & Turkey & NA & NA & NA \\
\hline Cho, 2009 [12] & $\begin{array}{l}200 \text { CT and plain } \\
\text { radiographics }\end{array}$ & 31 & $\begin{array}{l}\text { Retrospective } \\
\text { study }\end{array}$ & Korea & 45 mean & 14 in 100 & 17 in 100 \\
\hline $\begin{array}{l}\text { Karau, et al.. } 2010 \\
\text { [28] }\end{array}$ & $\begin{array}{l}204 \text { sides in } \\
\text { skeletons }\end{array}$ & 29 sides & NA & Kenya & NA & NA & NA \\
\hline $\begin{array}{l}\text { Kuhta, et al. } 2010 \\
\text { [26] }\end{array}$ & $\begin{array}{l}304 \text { lateral cervical } \\
\text { spine radiographics }\end{array}$ & 112 & NA & USA & NA & NA & NA \\
\hline $\begin{array}{l}\text { Koutsouraki, et al. } \\
2010 \text { [14] }\end{array}$ & Female patient & 1 & Case report & Greece & 18 & - & - \\
\hline $\begin{array}{l}\text { Schilling et al, } \\
2010[5]\end{array}$ & $\begin{array}{l}436 \text { Digital lateral } \\
\text { cephalometric }\end{array}$ & 84 & $\begin{array}{l}\text { Cross } \\
\text { sectional }\end{array}$ & Chile & 18,44 & 46 & 38 \\
\hline $\begin{array}{l}\text { Sharma, et al. } \\
2010[6]\end{array}$ & $\begin{array}{l}858 \text { Lateral } \\
\text { cephalometric }\end{array}$ & $37^{*}$ & NA & India & 15 & 21 & 16 \\
\hline $\begin{array}{l}\text { Travan, et al. } 2011 \\
\text { [8] }\end{array}$ & Female skeleton & 1 & Case report & Central Europe & $12-14$ & - & - \\
\hline $\begin{array}{l}\text { Chitroda, et al. } \\
2013 \text { [11] }\end{array}$ & $\begin{array}{l}500 \text { digital lateral } \\
\text { cephalography }\end{array}$ & 302 & NA & $\begin{array}{l}\text { Karnataka } \\
\text { region, India }\end{array}$ & $5-70$ & 158 & 144 \\
\hline
\end{tabular}


Closs et al.; BJMMR, 21(12): 1-10, 2017; Article no.BJMMR.30378

\begin{tabular}{|c|c|c|c|c|c|c|c|}
\hline Reference & Review source & $\begin{array}{l}\text { Total } \\
\text { prevalence }\end{array}$ & Study type & Population & Age & $\begin{array}{l}\text { Female } \\
\text { prevalence }\end{array}$ & $\begin{array}{l}\text { Male } \\
\text { prevalence }\end{array}$ \\
\hline $\begin{array}{l}\text { Bayrakdar, et al. } \\
2014 \text { [1] }\end{array}$ & $\begin{array}{l}\text { Considered only } \\
\text { complete Ponticulus } \\
\text { posticus }\end{array}$ & $127(17.4 \%)$ & Cohort & Turkey & $8-81$ & 73 & 54 \\
\hline $\begin{array}{l}\text { Elgafy, et al. } 2014 \\
\text { [29] }\end{array}$ & $100 \mathrm{CT}$ & 14 & $\begin{array}{l}\text { Retrospective } \\
\text { study }\end{array}$ & Italy & 47.1 mean & 5 & 9 \\
\hline $\begin{array}{l}\text { Mudit, et al. } 2014 \\
\text { [3] }\end{array}$ & $\begin{array}{l}650 \text { Lateral } \\
\text { cephalometric }\end{array}$ & 72 & NA & $\begin{array}{l}\text { Karnataka } \\
\text { region, India }\end{array}$ & 20 mean & 42 & 30 \\
\hline $\begin{array}{l}\text { Pérez, et al. } 2014 \\
\text { [30] }\end{array}$ & $\begin{array}{l}1056 \text { Lateral } \\
\text { cephalometric }\end{array}$ & 209 & NA & Peru & 14.05 mean & NA & NA \\
\hline $\begin{array}{l}\text { Sabir, et al. } 2014 \\
{[4]}\end{array}$ & $\begin{array}{l}200 \text { Lateral } \\
\text { cephalometric and } \\
\text { CBCT }\end{array}$ & 58 & NA & India & NA & NA & NA \\
\hline $\begin{array}{l}\text { Chen, et al. } 2015 \\
\text { [31] }\end{array}$ & 500 CBCT & 35 & $\begin{array}{l}\text { Retrospective } \\
\text { study }\end{array}$ & Taiwan & 44.8 mean & 23 & 12 \\
\hline $\begin{array}{l}\text { Sekerci, et al. } \\
2015 \text { [32] }\end{array}$ & 542 CBCT & 213 & $\begin{array}{l}\text { Retrospective } \\
\text { study }\end{array}$ & Turkey & 32.7 & 108 & 105 \\
\hline
\end{tabular}




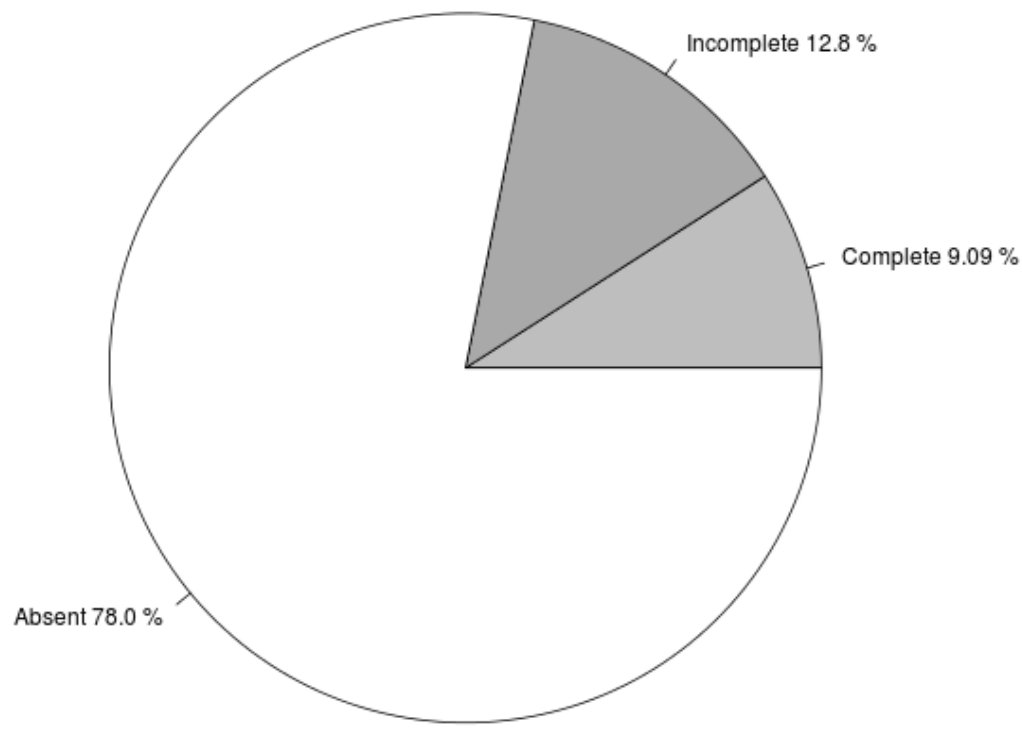

$\mathrm{n}=242$

Fig. 5. Distribution of Ponticulus posticus in sample

In general, literature and results of this study showed that the Ponticulus posticus incidence does not dependent on sex. This bone formation is due to congenital origin [6].

In the sample evaluated, our study showed that the Ponticulus posticus incidence cannot be related to the sexual dimorphism. Therefore, there was no sex influence in the presence of Ponticulus posticus, indicating that sex is not an influencing factor. Therefore, Ponticulus posticus cannot be used as a differential character in sex determination and thus does not contribute in human identification analysis of dental documents, such as radiographs. However, in the literature this anatomical variation was found with a clinical importance as one of the headache etiologies.

\section{CONCLUSION}

The present study concludes that the incidence of incomplete and complete Ponticulus posticus did not differ. But more important, Ponticulus posticus is an anatomical variation that cannot be related to sexual dimorphism.

\section{CONSENT}

All authors declare that 'written informed consent was obtained from the patient (or other approved parties) for publication of this paper and accompanying images'.

\section{ETHICAL APPROVAL}

All authors hereby declare that all experiments have been examined and approved by the appropriate ethics committee (Committee for Ethics of Research of the State University of Campinas - Protocol number CEP- FOPUNICAMP-014/2014) and have therefore been performed in accordance with the ethical standards laid down in the 1964 Declaration of Helsinki.

\section{COMPETING INTERESTS}

Authors have declared that no competing interests exist.

\section{REFERENCES}

1. Bayrakdar IS, Miloglu $O$, Altun $O$, Gumussoy I, Durna D, Yilmaz AB. Cone beam computed tomography imaging of Ponticulus posticus. Prevalence, characteristics, and a review of the literature. Oral Surg Oral Med Oral Pathol Oral Radiol. 2014;118(6):e210e219. 
2. Bezerra AJC, Macedo HL, Bezerra ACA, Di Dio LJ. Atlas com Ponticulus posticus bilateral. Brasília Med. 2001;38(1-4): 33-37.

3. Mudit G, Srinivas K, Satheesha BR. Retrospective analysis of Ponticulus posticus in indian orthodontic patients-a lateral cephalometric study. Ethiop $\mathrm{J}$ of Health Sci. 2014;24(4):285-290.

4. Sabir H, Kumbhare S, Rout P. Evaluation of Ponticulus posticus on digital lateral cephalograms and cone beam computed tomography in patients with migraine and healthy individuals. A comparative study. Oral Surg Oral Med Oral Pathol Oral Radiol. 2014;118(3):348-354.

5. Schilling J, Schilling A, Suazo Gl. Ponticulus posticus on the posterior arch of Atlas, prevalence analysis in asymptomatic patients. Int J Morphol. 2010;28(1):317322.

6. Sharma V, Chaudhary D, Mitra R. Prevalence of Ponticulus posticus in Indian orthodontic patients. Dentomaxillofac Radiol. 2010;39:277-283.

7. Simsek S, Yigitkanli K, Comert A, Acar HI, Seckin $\mathrm{H}$, Er U, et al. Posterior osseous bridging of C1. J Clin Neurosci. 2008;15: 686-688.

8. Travan L, Saccheri P, Sabbadini G, Crivellato E. Bilateral arcuate foramen associated with partial defect of the posterior arch of the atlas in a medieval skeleton. Case report and review of the literature. Looking backward to go forward. Surg Radiol Anat. 2011;33:495-500.

9. Wight S, Osborne N, Breen AC. Incidence of ponticulus posterior of the atlas in migraine and cervicogenic headache. $\mathrm{J}$ Manipulative Physiol Ther. 1999;22:15-20.

10. Young JP, Young PH, Ackermann MJ, Anderson PA, Riew KD. The Ponticulus posticus. Implications for screw insertion into the first cervical lateral mass. J Bone Joint Surg. Am. 2005;87A(11):2495-2498.

11. Chitroda PK, Katti G, Baba IA, Najmudin M, Ghali SR, Kalmath B, et al. Ponticulus posticus on the posterior arch of atlas, prevalence analysis in symptomatic and asymptomatic patients of gulbarga population. J Clin Diagn Res. 2013;7(12): 3044-3047.

12. Cho YJ. Radiological analysis of Ponticulus posticus in koreans. Yonsei Med J. 2009;50(1):45-49.

13. Haynes MJ, Cala LA, Melsom A, Mastaglia FL, Milne N, McGeachie JK. Posterior ponticles and rotational stenosis of vertebral arteries. A pilot study using Doppler ultrasound velocimetry and magnetic resonance angiography. $\mathrm{J}$ Manipulative Physiol Ther. 2005;28:323329.

14. Koutsouraki E, Avdelidi E, Michmizos D, Kapsali SE, Costa V, Baloyannis S. Kimmerle's anomaly as a possible causative factor of chronic tension-type headaches and neurosensory hearing loss: Case report and literature review. Int $\mathrm{J}$ Neurosci. 2010;120:236-239.

15. Kim KH, Park KW, Manh TH, Yeom JS, Chang BS, Lee CK. Prevalence and morphologic features of Ponticulus posticus in Koreans. Analysis of 312 radiographs and 225 three-dimensional CT Scans. Asian Spine J. 2007;1(1): 27-31.

16. Ahmed AA. Estimation of sex from the lower limb measurements of Sudanese adults. Forensic Sci Int. 2013;229(1-3): 169.e1-169.e7.

17. Ceballos JL, Rentschler EH. Roentgen diagnosis of sex based on adult skull characteristics; Comparison study of cephalometry of male and female skull films (frontal pro-projection). Radiology. 1958;70:55-61.

18. Hsiao TH, Chang HP, Liu KM. Sex determination by discriminant function analysis of lateral radiographic cephalometry. J Forensic Sci. 1996;41: 792-795.

19. Patil KR, Mody RN. Determination of sex by discriminant function analysis and stature by regression analysis: A lateral cephalometric study. Forensic Sci Int. 2005;147:175-180.

20. Townsend GC, Richards LC, Carroll A. Sex determination of Australian aboriginal skulls by discriminant function analysis. Aust Dent J. 1982;27:320-326.

21. Veyre-Goulet SA, Mercier C, Robin O, Guerin C. Recent human sexual dimorphism study using cephalometric plots on lateral teleradiography and discriminant function analysis. J Forensic Sci. 2008;53:786-789.

22. Satheesha N. Abnormal foramina on the posterior arch of Atlas. International Journal of Anatomical Variantions. 2008; 1:21-22.

23. Keskil S, Gozil R, Calguner E. Common surgical pitfalls in the skull. Surg Neurol. 2003;59:228-231. 
24. Satheesha N. Bilateral absence of foramen transversarium in atlas vertebra: A case report. Neuroanatomy. 2007;6:28-29.

25. Satheesha N. Asymetric Atlas assimilation and potential danger to the brainstem: $A$ case report. The Internet Journal of Biological Anthropology. 2008;1.

26. Kuhta P, Hart J, Greene-Orndorff L, McDowell-Reizer B, Rush P. The prevalence of posticus ponticus. Retrospective analysis of radiographs from a chiropractic health center. J Chiropr Med. 2010;9:162-165.

27. Krishnamurthy A, Nayak SR, Khan S, Prabhu LV, Ramanathan LA, Ganesh Kumar C, et al. Arcuate foramen of atlas: Incidence, phylogenetic and clinical significance. Rom J Morphol Embryol. 2007;48:263-266.

28. Karau Bundi P, Ogeng'o JA, Hassanali J, Odula PO. Morphometry and Variations of Bony Ponticles of the Atlas Vertebrae (C1) in Kenyans. Int J Morphol. 2010;28:10191024.
29. Elgafy H, Pompo $F$, Vela R, Elsamaloty $\mathrm{HM}$. Ipsilateral arcuate foramen and highriding vertebral artery. Implication on C1C2 instrumentation. Spine J. 2014;14: 1351-1355.

30. Pérez IE, Chávez AK, Ponce D. Frequency of Ponticulus posticus in Lateral Cephalometric Radiography of Peruvian Patients. Int J Morphol. 2014;32: 54-60.

31. Chen $\mathrm{CH}$, Chen $\mathrm{YK}$, Wang CK. Prevalence of ponticuli posticus among patients referred for dental examinations by cone-beam CT. Spine J. 2015;15: 1270-1276.

32. Sekerci AE, Soylu E, Arikan MP, Aglarci OS. Is there a relationship between the presence of Ponticulus posticus and elongated styloid process? Clin Imaging. 2015;39:220-224.

33. Cederberg RA, Benson BW, Nunn M, English JD. Arcuate foramen. Prevalence by age, gender, and degree of calcification. Clin Orthod Res. 2000;3:162-167.

(c) 2017 Closs et al.; This is an Open Access article distributed under the terms of the Creative Commons Attribution License (http://creativecommons.org/licenses/by/4.0), which permits unrestricted use, distribution, and reproduction in any medium, provided the original work is properly cited.

Peer-review history:

The peer review history for this paper can be accessed here: http://sciencedomain.org/review-history/19350 